\title{
Sudden Cardiac Death, Haemodialysis, Hydroxychloroquine, and COVID-19
}

\author{
Viroj Wiwanitkti \\ Honorary Professor, Dr DY Patil University, Pune, India
}

Dear Editor,

I read the publication on "Sudden Cardiac Death in Haemodialysis Patients under Hydroxychloroquine (HCQ) Treatment for COVID-19: A Report of Two Cases" with great interest [1]. In this report, "Potential risks contributing to sudden cardiac death during HQtreatment of ESRD patients are discussed [1]." Cardiac adverse effects due to HCQ are an important consideration in clinical practice. The problem might occur in any patient regardless of ESRD or not. The important questions are whether HCQ is safe for the ESRD patient or not and whether the sudden death in the present report by Murt et al. [1] is due to the disease or adverse effect of HCQ. In a recent report, HCQ was proven safe for the ESRD patient, but routine monitoring of EKG was recommended, similar to that in general people who receive the drug [2]. Regarding cardiac arrhythmia, it is a use [3]. possible complication of COVID-19 regardless of HCQ

\section{Conflict of Interest Statement}

The author has no conflicts of interest to declare.

\section{Funding Source}

There is no funding.

\begin{tabular}{|c|c|}
\hline References & $\begin{array}{l}1 \text { Murt A, Dincer MT, Karaca C. Sudden car- } \\
\text { diac death in haemodialysis patients un- } \\
\text { der hydroxychloroquine treatment for CO- } \\
\text { VID-19: a report of two cases. Blood Purif. } \\
2020 \text { Oct 8:1-3. } \\
2 \text { Giaime P, Guenoun M, Pedinielli N, Nar- } \\
\text { bonne H, Bergounioux JP, Solas C, et al. Hy- } \\
\text { droxychloroquine and azithromycin toler- } \\
\text { ance in haemodialysis patients during CO- } \\
\text { VID-19 infection. Nephrol Dial Transplant. } \\
\text { 2020 Aug 1;35(8):1346-53. } \\
3 \text { Turagam MK, Musikantow D, Goldman ME, } \\
\text { Bassily-Marcus A, Chu E, Shivamurthy P, et } \\
\text { al. Malignant arrhythmias in patients with } \\
\text { COVID-19: incidence, mechanisms and out- } \\
\text { comes. Circ Arrhythm Electrophysiol. } 2020 \\
\text { Nov;13(11):e008920. }\end{array}$ \\
\hline
\end{tabular}

